https://doi.org/10.17816/MAJ191S139-41

\title{
PROTEASOME MECHANISMS OF THE DEVELOPMENT OF TOLERANCE TO ALLOGRAFT IN WISTAR AND AUGUST RATS WITH DIFFERENT CONTENT OF MONOAMINES IN THE BRAIN
}

T.M. Astakhova', Ya.D. Karpova ${ }^{1}$, G.A. Bozhok ${ }^{2}$, N.M. Alabedal'karim ${ }^{2}$, Yu.V. Lyupina , E.I. Legach ${ }^{2}$, N.P. Sharova ${ }^{1}$

${ }^{1}$ Koltzov Institute of Developmental Biology, Russian Academy of Sciences, Moscow, Russia;

${ }^{2}$ Institute of Problems of Cryobiology and Cryomedicine, National Academy of Sciences of Ukraine, Khar'kov, Ukraine

\section{ПРОТЕАСОМНЫЕ МЕХАНИЗМЫ РАЗВИТИЯ ТОЛЕРАНТНОСТИ К АЛЛОТРАНСПЛАНТАТУ У КРЫС ВИСТАР И АВГУСТ С РАЗНЫМ СОДЕРЖАНИЕМ МОНОАМИНОВ В ГОЛОВНОМ МОЗГЕ}

\author{
Т.М. Астахова ${ }^{1}$, Я.Д. Карпова ${ }^{1}$, Г.А. Божок², Н.М. Алабедалькарим², Ю.В. Люпина ${ }^{1}$ \\ Е.И. Легач ${ }^{2}$ Н.П. Шарова ${ }^{1}$ \\ ${ }^{1}$ ФГБУН «Институт биологии развития им. Н.К. Кольцова» РАН, Москва; \\ ${ }^{2}$ Институт проблем криобиологии и криомедицины НАН Украины, Харьков
}

The aim of the work was to compare proteasome mechanisms of the development of donor-specific tolerance (DST) to ovarian allograft in outbred Wistar rats and inbred August rats with the increased level of monoamines and stress limiting systems in the brain. In spite of DST induction in all animals, engraftment was more effective in Wistar rats. In the liver of all rats with survived allograft, the level of proteasome immune subunt LMP2, evaluated by Western blotting, was significantly higher than in control false-operated rats. This difference was more pronounced in Wistar rats. Besides, in the liver of all rats with survived allografts, the level of proteasome PA28 $\alpha \beta$ activator was higher than in control. In conclusion, the development of DST is connected with the enrichment of liver proteasome pool by immune forms containing LMP2 subunit and PA28 $\alpha \beta$ activator. This process is partially suppressed in August rats under stress conditions of the central nervous system.

Keywords: proteasomes; donor-specific tolerance; ovarian allograft; stress of central nervous system.

Цель настоящей работы - сравнить протеасомные механизмы развития донор-специфической толерантности (ДСТ) к аллографту ткани яичников у аутбредных крыс Вистар и инбредных крыс Август с повышенным уровнем моноаминов и стресс-лимитирующих систем в головном мозге. Несмотря на индукцию ДСТ у всех животных, приживление аллографта было более эффективным у крыс Вистар. В печени всех крыс с прижившимся аллографтом уровень иммунной субъединицы LMP2 протеасом, по данным Вестерн-блоттинга, был значительно выше, чем у контрольных ложно-оперированных животных. Эта разница была более выражена у крыс Вистар. Кроме того, в печени всех крыс с прижившимся аллографтом уровень активатора РА28 $\alpha \beta$ протеасом был выше, чем в контроле. В заключение, развитие ДСТ связано с обогащением пула протеасом печени иммунными формами с субъединицей LMP2 и активатором РA28 $\alpha \beta$. Этот процесс частично подавлен у крыс Август в условиях стресса центральной нервной системы.

Ключевые слова: протеасомы; донор-специфическая толерантность; аллографты ткани яичников; стресс центральной нервной системы.

Introduction. Induction of donor-specific tolerance (DST) by infusion of donor cells into portal vein of a recipient $7-14$ days before grafting a tissue is the effective approach to prolong the life of a graft [1]. Molecular mechanisms of DST development are still poor studied. We showed earlier that in inbred August rats the enhanced expression of liver immune proteasomes with LMP2 subunit was related to the survival of ovarian allograft [2]. Inbred August rats are known to have the increased level of monoamines and stress limiting systems in the brain in comparison with outbred Wistar rats [3]. The aim of the present work was to compare proteasome mechanisms of the development of DST to ovarian allograft in August and Wistar rats being under different stress conditions of the central nervous system.

Material and methods. Ovarian grafts from neonatal Wistar and August rats were transplanted to 5-6-month-age female August rats $(n=10)$ and Wistar rats $(n=10)$, correspondingly, as earlier described [2] with the exception of preliminary ovariectomy. DST was induced in every rat group 7 days before ovarian grafting as described previously [2]. False-operated animals (intraportal infusion of pure physiological saline solution and simulation of grafting) $(n=5)$ were used as a control. All manipulations on animals were performed 
Table 1

Content of proteasome subunits in the liver of rats with rejected or survived ovarian tissue on 39 day after its grafting

\begin{tabular}{|l|c|c|c|c|}
\hline \multirow{2}{*}{ Proteasome subunits } & \multicolumn{3}{|c|}{ Content of proteasome subunits, normalized to $\beta$-actin level, \% to control } \\
\cline { 2 - 5 } & \multicolumn{2}{|c|}{ Rats with rejected allograft } & \multicolumn{2}{c|}{ Rats with survived allograft } \\
\cline { 2 - 5 } & August rats & Wistar rats & August rats & Wistar rats \\
\hline LMP7 & $96 \pm 15$ & $104 \pm 21$ & $112 \pm 31$ & $102 \pm 25$ \\
\hline LMP2 & $72 \pm 10^{*}$ & $58 \pm 13^{*}$ & $159 \pm 27^{*}$ & $305 \pm 52^{*}$ \\
\hline Rpt6 & $64 \pm 20$ & $70 \pm 19$ & $42 \pm 12^{*}$ & $50 \pm 14^{*}$ \\
\hline PA28 $\alpha$ & $106 \pm 19$ & $95 \pm 23$ & $235 \pm 34^{*}$ & $259 \pm 41^{*}$ \\
\hline
\end{tabular}

Note. Standard deviation is shown; * reliable difference from control at $p<0.05$.

in accordance with the European Convention on the Protection of Vertebrate Animals used for Experimental and Other Scientific Purposes (Strasburg, 1986). Detection of proteasome subunit content was performed by Western blotting in accordance with protocol published previously [3].

Results and discussion. In spite of DST induction, the tolerance to allografts was not developed in all cases. In 7 of 10 Wistar rats and 4 of 10 August rats, the ovarian tissue survived to 39 day after its grafting. Stress conditions due to the enhanced monoamine level in the brain are likely to be related to not-so-effective DST development and engraftment in August rats as in Wistar rats. The content of proteolytic immune subunits LMP7 and LMP2 and subunits Rpt6 and PA28 $\alpha$ belonging to proteasome activators PA700 and PA28 $\alpha \beta$, correspondingly, in the liver of all groups of rats was studied (fig. 1, table 1).

In the liver of all rats with survived allografts, LMP2 content was significantly higher, while in the rats with rejected allografts it was lower than in control rats. Importantly, these differences were more pronounced in Wistar rats. LMP7 content in the liver did not differ between all groups of animals. The level of PA28 $\alpha \beta$ activator was increased and the level of PA700 activator was decreased in the liver of August and Wistar rats with survived allografts compared to control.

$\frac{1}{A \quad W} \frac{2}{A \quad W} \frac{3}{A \quad W}$

LMP7 (26 kDa)

LMP2 (23 kDa)

Rpt6 (48 kDa)

PA28 $\alpha(28 \mathrm{kDa})$

$\beta$-Action (43 kDa)

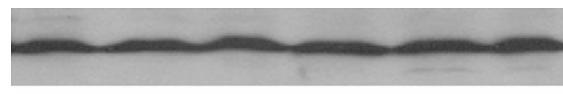

Fig. 1. Western blots of liver proteasome subunits of control rats (1) and rats with rejected (2) or survived ovarian tissue (3) on 39 day after its grafting. A, August rats; W, Wistar rats

Conclusion. Thus, the development of DST is connected with the enrichment of liver proteasome pool by immune proteasomes containing LMP2 subunit and PA28 $\alpha \beta$ activator, which may be important for inhibition of $\mathrm{T}$ lymphocyte function. Rebuilding of liver proteasome pool is partially suppressed in August rats by stress condition of their central nervous system.

Acknowledgments. This work was funded by RFBR (grant No. 16-34-60083-mol_a_dk) and Government Program of Basic Research (No. 0108-2018-0002).

\section{References}

1. Karpova YaD, Bozhok GA, Alabedal'karim NM, et al. Proteasomes and transplantology: Current state of the problem and the search for promising trends. Biology Bulletin. 2017;44(3):237-244.

2. Karpova $\mathrm{YaD}$, Bozhok GA, Lyupina $\mathrm{YuV}$, et al. Changes in the proteasome function after Induction of donor-specific tolerance in rats with ovarian allograft. Biology Bulletin. 2012;39(3):244-249.

3. Erokhov PA, Lyupina YuV, Radchenko AS, et al. Detection of active proteasome structures in brain extracts: Proteasome features of August rat brain with violations in monoamine metabolism. Oncotarget. 2017;8:70941-70957. 